Kohl: a Journal for Body and Gender Research

Vol. 1, No. 2 (Winter 2015)

\title{
Battles with Desires: \\ Centering the Body in the Personal Narratives of Doria Shafik and Latifa El-Zayyat
}

\author{
Salma Shash
}

\begin{abstract}
:
As two key figures of Egyptian feminism, Doria Shafik (1908-1975) and Latifa El-Zayyat (1923-1996) are well-known for their public activism. In this paper, however, I am interested in re-reading Shafik's biography Doria Shafik an Egyptian Feminist: a Woman Apart (Nelson, 1996) and El-Zayyat's autobiography The Search: Personal Papers (1996) with an eye on the position of the body in their battles for equality and freedom. Although the "body" and "sexuality" are not part of the feminist and literary narratives about these women, I focus on their intimate reflections on femininity, love, and marriage. I intend to show how their female bodies remained particularly relevant, as their appearances and their desires were used against them, even when they did not explicitly transgress sexual and gender norms. In fact, Shafik and El-Zayyat themselves were able to confront political repression more readily than the suppression of their own bodies and sexuality. However, despite it being the locus of external and internal oppressions, the activists discussed here transformed their bodies into a tool of resistance at later stages of their lives, especially through their experiences of imprisonment. I situate this argument within the context of the post-colonial nation to emphasize that women's bodies were not automatically freed with national independence, despite the post-colonial project's revolutionary credentials and emancipatory promises for women.
\end{abstract}




\section{Introduction}

"Some day

Spring will blossom again

In a free, free land,

Where we can live again,

Where we can love and be loved again."

(El-Zayyat, 1996, p. 63)

In 1949, Latifa El-Zayyat, a political prisoner at the time, defiantly repeated these verses in court (ElZayyat, 1996). A few years later, Egypt was freed from British occupation. Yet, whether her country became "a free, free land" where El-Zayyat, as a leftist activist and as a woman, "can love and be loved," is more contestable. To many Egyptian activists, the revolutionary and nationalist effervescence tied to the post-colonial project was about more than freedom from the colonial yoke. To many women, as the verses tell, it was about a future that promised equality and a "new era of love and liberty" (Shafik qtd in Nelson, 1996, p.185). The emphasis on love in El-Zayyat's song is to be taken metaphorically, as women hoped for a new nation that reciprocates their love as full and equal citizens, but perhaps also literally and simply as the longing for a home where they can freely fall in love.

However, the post-colonial nation fell short on many of its promises regarding personal and political freedoms. Ruled by Gamal Abdel Nasser and his successors, the Egyptian state remained an authoritarian one that did not welcome dissent. Moreover, this authoritarian government was founded on patriarchal structures, as the post-colonial nation did not deliver on many of its promises to women after independence. Thus, Egyptian women endured and resisted decades of subjugation to the persisting alliance between authoritarianism and patriarchy. In this paper, I particularly focus on two Egyptian activists who committed their lives to battling authoritarian and patriarchal structures: Doria Shafik (19081975) and Latifa El-Zayyat (1923-1996). I examine Shafik's biography written by Nelson (1996), which was based on Shafik's unpublished memoirs, and El-Zayyat's autobiography (1996) from which the above verses were taken. My reading of these feminist texts focuses on the place of the "body" in their stories of resistance, and in particular the ways in which women's bodies and desires were formulated as tools of oppression, liberation, or a compromise between the two.

Shafik and El-Zayyat are well-known as two key figures in the history of Egyptian feminism. Even though their lives have been made publicly visible by feminists, their public activism and the difficult battles they fought for gender equality and political rights are most salient. In this paper, I am interested in re-reading their life stories with an eye on the position of the body in their battles for equality, freedom, and love. The importance of examining the body in these women's stories is twofold. First, Shafik and El-Zayyat are not particularly known for having non-conforming bodies. They did not transgress the mainstream expectations of heterosexual desire, and nothing was particularly defiant in their self-presentation. In fact, their feminist activism was not centred on liberating women's bodies or on sexual freedoms, like other Egyptian feminists such as Nawal Al-Saadawi. I find it important to understand the ways in which the body is relevant, not only in stories of explicit challenging of gender and sexual norms. Second, I situate this understanding of the two women's bodies within the post-colonial context as a particular moment of 
transition in the history of $20^{\text {th }}$ century Egypt. Taken together, Shafik and El-Zayyat's biographies start in monarchical Egypt and end with Sadat's presidency. The coming of age of their feminist consciousness coincides with the formation of a collective national consciousness and the birth of the post-colonial nation. The advent of revolution and independence promised the liberation of women in the "modern" nationalist project (Bier, 2011, p. 3). Women's participation in the labour force statistically increased after independence, and they did officially obtain some of their political rights as equal citizens (Bier, 2011). ${ }^{1}$ However, "liberation" was still far from being achieved when it came to women's bodies. Reading these texts captures the moment of the birth of a post-colonial state, and the hopes and frustrations that precede and follow it from these two women's perspective. Focusing on their intimate reflections on love, femininity, and marriage shows a continuum of women's oppression, especially through their bodies, before and after Egypt's independence.

Shafik and El-Zayyat's long history of activism in critical moments of Egyptian history makes their stories pertinent. The time span of the biographical and autobiographical texts under study here provides a rare insight into an extended period of Egyptian history, which can rarely be found in any other autobiography/biography of Egyptian feminists. Nonetheless, it is important to clarify that these stories remain cases of illustration and not representation. Shafik and El-Zayyat were privileged women in terms of class and education. Just as they do not represent all Egyptian women, they also do not represent the very heterogeneous category of women activists, as there were different types of activists between liberals, Islamists, and leftists, cross-cutting different age groups, classes, and regions.

In this paper, I argue that Shafik and El-Zayyat's depictions of their lives highlight how the activists' bodies, their appearance and their sexualities were used against them. In fact, I suggest that Shafik and El-Zayyat were better able to confront political oppression than the repression of their own bodies and desires. However, at later stages of their lives, both women were able to view their bodies as tools of resistance, especially during their experiences of imprisonment.

\section{Contextualizing the analysis}

Before engaging in an analysis of the texts, a brief summary of both women's lives is necessary. Shafik, an Egyptian feminist, poet and activist, was born in 1908 to a middle-class family. She travelled to France to earn her $\mathrm{BA}$ and $\mathrm{PhD}$, and became increasingly active upon her return to Egypt. Shafik's activism started with an interest in the feminist cause. In 1936, she edited the magazine La Femme Nouvelle, which focused on literary and cultural issues. In 1945, she started her own magazine, Bint el-Nil, published in Arabic to reach a wider audience. These publishing experiences led Shafik to found a feminist organization - "Bint el-Nil Union" - in 1948, which started advocating more openly for gender equality and women's liberation. Shafik began moving slowly from feminist frameworks, which were not in direct opposition to state authority, ${ }^{2}$ to much more confrontational and politically daring tactics. Her activism intensified during the last years of the monarchy and during Nasser's era. In 1951, she stormed

\footnotetext{
1 These rights include the right to vote granted by the 1956 constitution, as a result of women's continuous activism, including a hunger strike in the press syndicate led by Doria Shafik in 1954 (Nelson, 1996; Bier, 2011). Liberation here is used in the sense of freedom from all sorts of oppression and external control.

2 La Femme Nouvelle was initially edited in collaboration with princess Shoueikar, a member of the royal family.
} 
the parliament and occupied the office of the president of the senate to demand women's equal representation in the legislature, as well as other political rights. She also lobbied for the reform of the laws on polygamy and divorce. She led two hunger strikes in 1954 and 1957, not only for gender equality, but against Nasser's dictatorship. The latter put her under house arrest in 1957, after which she remained in self-seclusion until her probable suicide in 1975.

Doria Shafik: An Egyptian Feminist is a biography written by Cynthia Nelson, but that relies heavily on Shafik's unpublished memoirs. It was also written in close collaboration with her daughters (Nelson, 1996). It can be read as a semi-autobiography, since it draws mainly on Shafik's writing, with Nelson providing the historical context. Despite Nelson's important contextualization, the purpose of this paper is to focus on women's narration of their own stories and their self-reflections on intimate matters like love and their bodies. Therefore, I mainly focus on the sections written by Shafik herself. Examining Shafik's most active years, the earlier part of the biography relies mostly on her writings and provides enough material to explore her life through her own voice. In fact, she was quite prolific, writing not only her memoirs, but engaging in poetry and journalism as well (Nelson, 1996). Nelson contributed more than Shafik in writing about the activist's life after her house arrest, because the activist produced less writings during that period.

Like Shafik, El-Zayyat also came from an Egyptian middle-class family. Born in 1923 in Damietta, ElZayyat's political life may have begun at the age of eleven, when she saw from her window protestors getting shot by the police. This incident deeply affected her and contributed to her decision to commit to activism at this very young age. Attending Cairo University, she quickly became a leader in her political student group and joined the communist party under the monarchy. Early in her activism, she was determined to prove that women are not inferior to their male counterparts and can lead nationalist struggles. In 1949, she was arrested and imprisoned with her first husband, Ahmed Shoukry Salem. In 1952, El-Zayyat remarried Rashad Roushdy, a professor known for his right-wing and conservative opinions, despite her being a leftist activist. The marriage lasted for thirteen years until 1965 , during which El-Zayyat suspended her political activities. However, she earned her PhD in 1957 and published her most important novel The Open Door, described by many as a "bold feminist manifesto" (Bier, 2011). She resumed her political activities after the defeat of 1967 and later joined Al Tagamu' party, the only legalized leftist party under Sadat. She was arrested again in 1981 (El-Zayyat, 1996). Although, she never joined a women's movement, her feminist activism happened through her engagement in politics as well as through her writings, including her autobiography (El-Zayyat, 1996).

Indeed El-Zayyat's autobiography, The Search: Personal Papers, is a unique text. She divided the book into two parts, each focusing on very specific events in her life. The first part describes her life before her 1981 imprisonment; it particularly explores her early activism and first imprisonment, her second marriage and the defeat of 1967, and the death of her brother, all of them narrated non-chronologically. The second part of the book solely focuses on her 1981 imprisonment in Al-Qanater women's prison. Although she died in 1996, the autobiography ends in 1981, as she self-reflects on how her second imprisonment changed her. The most striking part in El-Zayyat's autobiography remains the way in which the public and the private are interwoven as one and the same, as well as the non-chronological sequence of events, which also demonstrates her interweaving of different time periods. She described 
her life as "taking a circular path" (El-Zayyat, 1996, p. 19) rather than a linear one, where past/present grief and private/public battles were all strongly entangled.

To bring the lives of these two women together and understand the centrality of the body in their struggles, I rely on content analysis of the texts, while linking certain events to broader political contexts when relevant. Rather than explaining the relevance of the body in feminist struggles, I explore how Shafik and El-Zayyat came to understand the significance of their own female bodies as political and intimate objects. Due to the age difference, Shafik's activism started earlier in pre-independence Egypt, while El-Zayyat's extended further during Sadat's era. Therefore, the period studied here extends from pre-independence in Egypt, criss-crossing the making of the postcolonial Nasserist state, and touching briefly on Sadat's era. "Authoritarianism" is used to describe undemocratic political regimes, while "patriarchy" represents both the hierarchal structures that allow male domination and the "domination of the father over his kinship" (Ramazanoglu, 1989, p. 34).

\section{Politicizing the Body: The Body as a Public Object}

Carol Hanisch's "the personal is political" disputes the public/private binary in gender theory (qtd in Lee, 2007). The politicization of what has been hitherto labelled as "personal issues" points to "broadening the concept of power to show that the private domain is as public and as political" (Ramazanoglu, 1989, p. 63). The body - the most intimate instrument - is also a public one that is not only experienced privately, but that is defined and affected by overarching power dynamics. As political dissidents, Shafik and ElZayyat did not conform to the state's expectation of docile bodies that belong to the private sphere or limit their presence in the public sphere to work or education. In 1949, Shafik was arrested under the monarchy for being a communist; in 1981, she was imprisoned under Sadat as a member of Al-Tagamu' party (El-Zayyat, 1996). Nasser's regime did not tolerate Shafik's activism for long either, as she was put under house arrest in 1957 (Nelson, 1996). Thus, throughout the different historical eras, the face of authoritarianism remained the same: not only did their controlled bodies mark them as political/ideological opponents, but they also highlighted their realities as women.

Because authoritarianism is a gendered structure, El-Zayyat's and Shafik's female bodies became more visible and were often used against them (Al-Nowaihi, 2001). As Enloe (2000) succinctly puts it, a woman's femininity is seen as the only "space through which she can take political action" (p. 20). That is, women's political activism is primarily perceived and explained through their gender. During her first imprisonment in 1949, the interrogator asked El-Zayyat: "Why are you concerned with politics when you are pretty?" (El-Zayyat, 1996, p.95). Therefore, his question denotes the gendered gaze towards women's activism: when interrogating her, state authorities constructed her as a woman before they could see the communist opponent in her. The interrogator's question also implies that activism may only be undertaken by someone who has some "defect" or "shortcoming" in their femininity, body, and even perhaps their morality. According to him, pretty women do not need to be political dissidents. In short, the interrogator used her gender to dismiss and shame her. During her second imprisonment in 1981, ElZayyat had to face a more visible form of this gendered state repression, especially with prison searches that intended to humiliate inmates. El-Zayyat wrote about the guards who hid her belongings, forcing her to stand naked in front of the male and female prison guards (El-Zayyat, 1996). As Al-Nowaihi (2001) 
argues, "repression on the basis of gender and on the basis of political activism are closely related [...] in the very structures of power that attempt to silence opposition" (p. 495). In El-Zayyat's case, her naked body represents the double subjugation to political authoritarianism and patriarchy: the guards were both representatives of the state and gazers at her female body, and she was facing them as both a dissident and a woman.

Shafik's biography also reveals the gendered state repression she faced in her early activist life, as her appearance was used by men in power to discriminate against her. She came back from France hopeful that her PhD with honours would earn her an appointment in the Faculty of Letters. However, she was met by categorical rejection from the dean of the faculty who, in his own words, could not "take the responsibility of appointing a beautiful female teacher in the faculty" (Nelson, 1996, p.99). In both Shafik and El-Zayyat's lives, then, their appearances were reasons to dismiss them and their work.

Moreover, it is not only state agents who used women's bodies to dismiss their activism, but fellow nationalist activists as well, as Shafik's biography demonstrates. Shafik always embraced her femininity and cared about her appearance in a way that conformed to socially accepted standards of elegance and beauty. However, her critics highlighted her self-presentation to stigmatize her. In fact, many anti-colonial nationalists ridiculed her for her beauty and said that she resembled more a "lady of the salon" than an activist (Nelson, 1996). As such, she was cast aside as not "serious" enough, "too liberal," or "too westernized." Shafik, however, has undertaken some of the most radical actions in the history of Egyptian feminism. As one of her political tactics, she aggressively entered the parliament in 1951, forced the chamber of deputies open, and occupied the office of the president of the senate till he promised to consider her demands to give women their political rights, such as voting and representation in the parliament.

The media also ridiculed Shafik through a sarcastic focus on her body and her appearance. In 1957, Shafik began a hunger strike against Nasser's dictatorial rule. Back then, and after the nationalization of the Suez Canal, Nasser was at the peak of his popularity and his rule was largely uncontested (Nelson, 1996; Bier, 2001). Many newspapers - including some that were not owned by the state - responded by calling her a "perfumed woman" and by putting her face on the body of a belly dancer. ${ }^{3}$ Drawing her as a vain woman and a mere attention seeker, the media therefore used her femininity and her looks to shame her as she was engaging in fights for political freedoms and equality that few others dared enter. The media's reaction to Shafik illustrates how the female body in itself is understood as lacking the seriousness supposedly needed for political participation.

The incidents above reveal the extent of contradictions tied to the perception of women activists' bodies. While it would certainly not be acceptable for an activist to transgress norms of womanhood and femininity with a masculine gender expression, it was similarly unacceptable for her to be "too" feminine. Shafik's Parisian sense of fashion drove nationalists to label her as pro-imperialist and religious conservative figures, such as Sheikh Al-Azhar, to consider her a threat to Muslim values (Nelson, 1996). Whereas rarely would a man's clothing style matter in his activism, women's appearance carries a special importance. Hence, Shafik always had to communicate the right bodily disposition in the right place, and

3 This quote comes from the semi-governmental Al-Jomhouria newspaper (qtd in Nelson, 1996) 
was repeatedly seen as lacking (Ghannam, 2013). This double standard could be related to what Kandiyoti convincingly explains as the paradoxical and sensitive status of women in the post-colonial project. ${ }^{4}$ Women, then, are the markers of both modernity - as educated, working women - and tradition - as modest, chaste, and good wives (Kandiyoti, 1996). The presence of a feminine body in the public sphere that was not only fighting for women's political rights but also for the reform of the Sharia-inspired personal status law was troubling for many allies and enemies alike. ${ }^{5}$

\section{Battling the Self: Resisting the Body}

Activist women's bodies, as shown in this paper, are used by authorities and their representatives - from the media to police interrogators - as a mean to oppress and dismiss women and their work. Yet, patriarchy and oppression only operate through external agents, because it is evident that in some instances, Shafik and El-Zayyat accepted to compromise on the liberation of their bodies and desires. In fact, as Bourdieu explains, the body is never only privately experienced. Bodies are expressions of the social, cultural, and political interactions that surround the individual - or what Bourdieu calls the "habitus" - that predispose one to act, dress, and move in particular ways (qtd in Ghannam, 2013). Individuals do not consciously act according to the rules set by their habitus; the way they experience their most intimate realms of being such as their desires and sexualities are unconsciously formed by these interactions.

True to this idea of accepting the values and rules of her environment, Shafik developed while in France a friendship that soon turned into an unfinished love story with a French poet. When her Egyptian flatmates managed to expel her from the dorms for the alleged affair, she chose to repress her love for him and asked him to stop contacting her. One can read her abrupt ending of this relationship as succumbing to social pressure from her peers and to internalized conceptions about sin and virtue. Despite her political rebellion against injustice, Shafik also "shared the values of the middle class when it came to love" (Nelson, 1996, p.34). Even when the poet asked to marry her, she refused to enter the battle of marrying a foreigner from a different religion despite her feelings for him.

In her career, nonetheless, Shafik never shied away from battles. She fought to study philosophy at the beginning of her academic life. ${ }^{6}$ She clashed with King Farouk and Nasser over women's rights and political freedoms, and her life was riddled with incessant battles that were ahead of their time. ${ }^{7}$ However, these battles revolved around women's collective bodily and political rights, as she may have considered them as more worthy causes. When it came to her individual body and her personal desires, she perceived such social battles as selfish and perhaps shameful. As she reflected in her memoirs, her Egyptian entourage managed to make her associate "love" with "terror" (qtd in Nelson, 1996, p.50). For

\footnotetext{
${ }^{4}$ The post-colonial project here does not necessarily pertain to a temporal category that came after colonialism; it rather refers to the ideological essence of the nationalist project even before formal independence, and which was then embodied in the post-colonial state.

5 Shafik's focus on religious reform was especially in matters of polygamy and divorce.

6 Philosophy was not considered a "woman discipline." Instead, women were given a list of "women disciplines" to choose from, which Shafik refused.

${ }^{7}$ A prime example of such battles with society that were against the mainstream and ahead of their time is her opposition to the authoritarian tendencies of the free officers as early as 1954.
} 
many women back then, it may have been easier to fight public battles than intimate ones that had to do with their bodies and sexual desires.

As for El-Zayyat, her repression of her sexuality and her very body was more accentuated and had more dramatic consequences on her life. In fact, despite Shafik's conservatism in matters of love and sexuality, she always embraced her female body. In contrast, El-Zayyat was perplexed by her body until her second marriage. As a university student, El-Zayyat recalled walking quickly in the library hoping that no one would notice her curvaceous female figure (p. 103). As she put it, she "buried the woman so deep that she was no longer aware of her" (p. 103). In stark opposition, when she was carried by other men as she led demonstrations, she had no confusion towards her body. Protesting in public spaces was the only way she felt comfortable with her body, especially when it merged with a bigger entity, because "she no longer felt she had a body, she forgot that she was a woman at all" (p. 104).

El-Zayyat sought to erase her body as a woman through intellectual pursuits or through political activism, as if it no longer existed on its own. In turn, she constantly tried to stifle her sexuality. Her attempt to repress her body was a reflection of an urge to move beyond the confines of her gender role and expectations. That is, in wanting to forget that she was a woman, she was attempting to let go of her "fear of clashing with life" (p. 90). Yet, El-Zayyat was already "clashing with life" by facing the brutality of officers in demonstrations and by courageously facing prison in 1949. Like Shafik, El-Zayyat's anxieties about her personal life and her body seemed to present more insurmountable obstacles than prison. And for both El-Zayyat and Shafik, the language of fear and avoidance only entered their writings when the topics of their bodies, loves, and sexualities were brought up.

Why was being a woman or embracing sexuality a "clash with life," as El-Zayyat expressed it, but not political activism? I argue that women's confrontations with social constraints against their bodies require them to struggle with their inner selves before confronting external authorities, like family, society, or the state. If opposing colonialism, authoritarianism, and unequal gender hierarchies was clear in Shafik's and El-Zayyat's young consciousness, sexual freedoms and love were more ambiguous territories. These required a radical reshuffling of one's system of values, faith, and morality, and a re-questioning of one's very identity. This is not meant to undermine Shafik and El-Zayyat's other battles, for which they paid extremely high costs. Rather, it serves to understand the difficulty of challenging taboos related to the body and sexuality, even for such defiant women. Identity construction always happens through an interaction with the existing hegemonic structures (Ghannam, 2013).

Thus, as Shafik and El-Zayyat's self-internalized repression of love and sexuality shows, it is difficult for women to escape the snares of patriarchy when constructing their identities. Their anxieties towards their bodies were also related to the historical context in which they lived - a period of transition between the colonial and the post-colonial. This transition that promised to transgress oppression with freedom left them uncertain about the place of love and sexuality in the awaited liberation. As El-Zayyat reflects through the main character of Open Door, " we do not know if we are in a harem or not, or whether love is forbidden or not" (qtd in Bier, 2011, p. 24). Instead of clashing with the world to find out, she often rejected her body and locked its desires in a prison that was "the hardest of all" (El-Zayyat, 1996, p. 102).

8 The novel is, in fact, considered by many as a semi-autobiography (Bier, 2011). 
El Zayyat's denial of her womanhood at this early phase of her sexual coming of age, has, in her words, "distorted" the course of her life (El-Zayyat, 1996, p. 103). She explains that till her second imprisonment, she was living "with half her faculties as a human being" (El-Zayyat, 1996, p. 106), not as a woman. Upon her release from prison, it was time for the repressed half of her, the woman, to exist. This fragmentation of her being explains her second marriage to a right-wing professor in 1952: she presents him as the typical image of a patriarch who made her lose "the ability to choose, to move, to act, to do anything, for a long time" (El-Zayyat, 1996, p. 19). Following her marriage, she completely retreated from public activism till the Naksa in 1967.

Yet, El-Zayyat refuses to explain this paralysis as external oppression from a patriarchal husband alone, as she recognizes that she was the agent of her own oppression. She unapologetically justified her marriage to him through the power of sex, as he was the first person who "awakened the woman in her" (Al-Nowaihi, 2001, p. 494). "When did I lose my consciousness? During love? During sex?" she openly wondered (1996, p. 105). The marriage, as she finally understood it, was the revenge of the woman that she repressed for a long time (Al-Nowaihi, 2001). The body she had denied compromised with patriarchal oppression, even accepting it in order to experience sexual gratification and to enjoy another form of bodily freedom.

However, while El-Zayyat reconciled with her femininity, she repressed another deep desire - that of her political activism, which, as she repeatedly stated, gave a meaning to her life (El-Zayyat, 1996). She was again living with only "half her faculties," but this time, it was through denying her love of activism. Her retreat from politics and her immersion in her husband's soul implied that she understood her sexuality as something that she had to enjoy in secret and that was irreconcilable with her activism. At this point, her sexual desires became a source of repressing her political being. Despite realizing early on that she needed to end a marriage that compromised her existence, it took her thirteen years to bring herself to leave. She became a slave to his image of her as a desired woman; she listened to him "breathless, [...] telling her about the curve of her cheek, the tone of her voice" (p. 107).

El-Zayyat skilfully interweaves her marriage with the Egyptian political context. I read her stylistic choice of starting a chapter named "1967" - where we expect to read about the Naksa but in which she writes about her 1965 divorce - as a way of linking public battles and defeats to private ones (El-Zayyat, 1996). Throughout this chapter, there is an implicit amalgam between the images of the patriarch at home, that is, her husband (whom she married in 1952, the year of the revolution) and the patriarch at the level of the state, Nasser. I argue that this alternation between the two men is used to show how she lost her consciousness to both figures (El-Zayyat, 1996). Her divorce and the painful defeat of 1967, which she experienced "on a personal level" (El-Zayyat, 1996, p. 66), are knitted together as a sort of resurrection, a retrieval of her consciousness. She realized that she "should have said no more often" to both Nasser and her husband (El-Zayyat, 1996, p. 54).

This chapter is therefore a personal account of her disillusionment with the post-colonial project where the hopes of freedom, love, and liberty crumbled on all levels. Shafik too went through a similar, though a much earlier, disillusionment: in 1952 she wrote that "we are witnessing the great turning point that constitutes the crisis traversed by the woman of today: a passage from one moment to another moment 
of her history, a substitution of a new reality for another reality" (qtd in Nelson, 1996, p. 31). However, this new reality never came. Shafik was quickly disappointed with Nasser's project in 1954 when an allmale constitutional assembly was formed, and she started her lonely fight against Nasser. As Nelson (1996) describes it in her chapter title, it was like an awakening from "a false dream."

\section{The "Women's Prison": Freedom of/from the Body}

That oppression occurs through the body is clear, whether through violence, imprisonment, denying desires, or ridiculing a woman's self-presentation. However, at other instances, both activists also experienced liberation through their bodies. Paradoxically, both women mention freedom specifically in relation to prison, and they explain it as a freedom "from" the body rather than "of" the body. The concept of "prison" transcends its geographical confines, extending to private and political spaces. Shafik refers to the house she shared with her Egyptian colleagues in Paris and to her grandmother's house in Tanta as "prisons" (Nelson, 1996). El-Zayyat also speaks of her house with her second husband as selfimposed imprisonment (El-Zayyat, 1996). These invisible prisons were "all the more oppressive," as Shafik states (qtd in Nelson, 1996, p. 164). Thus, the "women's prison" is not solely located in Qanater where El-Zayyat was imprisoned or in Shafik's house arrest. It existed wherever they could feel the chains that curtailed their actions, whenever their moves were watched, and in the spaces where they were denied falling in love. In other words, "prison" took over every site where disciplinary power over the body was enacted.

In contrast, both women describe the actual experience of prison in terms of freedom. I do not mean to romanticize prisons or mitigate their horrors and difficulties, which both women recognize. In the case of Shafik, her house arrest led to a depression that eventually pushed her to her suicide in 1975. Yet, the association of prison with freedom illustrates what imprisonment taught these women about their own selves and bodies. El-Zayyat speaks of her first prison in 1949 as "home" (1996, p. 39). Although the space limited her movement, she was there as a result of her choices and her agency over her body in terms of political activism and physical presence in demonstrations.

Additionally, in the midst of the horror of prison arose a sense of freedom. Shafik explains that during her house arrest, "I existed in my most elevated sense; I was free" (qtd in Nelson, 1996, p. 257). It is an interesting way of understanding resistance: if she could not free her body as a political prisoner and as a woman, she could be freed from it. The oppression of her body gave way to her exploration of an inner life that the workings of power could not touch. As a vital tool of state repression, physical confinement made her realize that no matter how successful in controlling her body, the state could not reach and restrict her freedom of thought. During her house arrest, she stopped caring about her body, and in her words "lived with [her] soul" (qtd in Nelson, 1996, p. 204). Her resistance did not lie in fighting back for the liberation or control of her body; rather, she recognized that her freedom dwelled in her mind and consciousness.

This freedom of/from the body through imprisonment also appears in El-Zayyat's description of her second imprisonment in 1981. El-Zayyat speaks of this imprisonment as the most liberating experience of her life. Indeed, the second part of her book is solely dedicated to this period of epiphany that made 
her reconcile with her past. In the night where she stood naked in front of the prison guards (men and women), she finally felt free. Although initially hysterical, she eventually stopped trying to cover herself and accepted her nudity. In recognizing that they controlled her body, she realized that she controlled her feeling of shame. Only by deciding to stand unashamed did she turn a defeat into a triumph, a moment of humiliation into one of defiance. As she says, "I felt that the search did not concern me at all" (ElZayyat, 1991, p.109). This quote echoes Feldman's (1991) argument that "the body as the terminus locus of power also reflects the redirection and reversal of power" (p. 178). The exact same body that was supposed to stand in humiliation reversed the meaning of its subjugation by standing in indifference. At last, El-Zayyat had succeeded in turning her body into an instrument of resistance rather than one of oppression. It was only when she stood there proudly admitting defeat, not covering herself in front of political and gendered persecution, that she reconciled her femininity with her activism (El-Zayyat, 1996, p. 99). Her feminine body stopped being incompatible with her activism as was the case of her early political career. Rather, it became one of her strongest tools of resistance.

The first-hand experience of this moment does not define alone the act of resistance: El-Zayyat's honest account of it is a defiance to one of the most unutterable taboos in society, that of nudity (El-Zayyat, 1996; Abboud, 2006, p.). Her life stopped being circular and started taking a linear course, and the second part of the book dedicated to 1981 shifts to a chronological narration. Before this reconciliation between her different selves - the woman and the activist - she was trapped in a circular motion, always satisfying half of herself at the expense of the other, always returning to the point where she felt restrained and incomplete, which explains the non-linearity of time in the first part of the book (El-Zayyat, 1996).

\section{Conclusion}

Although the "body" and "sexuality" are not part of the feminist and literary narratives about the women activists Doria Shafik and Latifa El-Zayyat, a close reading of their (auto) biographies reveals the central role of their feminine bodies in their stories. In fact, by deconstructing the public/private dichotomy, we understand the body not as a private object, but one that conveys particular messages in the public sphere. The body, thus, is experienced privately according to the existing overarching power structures and social interactions. As such, the female body arises as the primary locus where power exercises its oppression over Shafik and El-Zayyat as activists and as women. Interestingly, it also arises as a site of compromise of their own freedom. Later in their lives, they succeed in different ways to subvert the body into a tool of resistance rather than one of oppression.

In the post-colonial context, this understanding of the body gains a specific importance for many reasons. Although the nationalist project's discourse was centred on revolutionary credentials that promised women's liberation alongside independence, women's bodies were not automatically freed with national independence - in fact, it was quite the opposite. This moment left many women - and certainly Shafik and El-Zayyat - perplexed with regards to their own bodies and sexualities, trapped between "desire and expectation" (Bier, 2011, p. 24). Perhaps the nationalist project gave women a greater access to the public sphere, as they participated in the anti-colonial struggle, gained some political rights, and experienced an increased presence in the workforce after the birth of the post-colonial nation. However, this access to the public sphere was far from unconditional; it was associated with controlling the female 
body as the repository of modernity and tradition. Because female bodies became the emblem of the post-colonial nation, sexual freedoms and the liberation of the body remained uncontested terrains, as they would have undermined the very basis of the newly independent nation. Rather than liberating them, the post-colonial project invented new means of controlling women's bodies. During this historical moment, the public and the private were particularly interlaced, and women like Shafik and El-Zayyat tied their lives to the national cause. It is therefore understandable that, in many instances, they internalized these ambiguities with regards to their own bodies.

The texts under study could be seen as a medium of resistance, allowing us to go beyond metanarratives of Egyptian history. They dispute the existence of one linear trajectory of "el mara'a el masryia" (the Egyptian woman) in singular terms (Bier, 2011) from oppression to liberation. Rather, Shafik and ElZayyat's life stories, spanning from the monarchy to Sadat's era, read like a reverse of mainstream Egyptian history. They recount the stories of women who did not become free-er after independence, but were rather physically and forcefully removed from the public sphere through imprisonment. More importantly, their daily lives and their experiences in love and marriage are far from indicating that they lived more freely or enjoyed a greater agency towards their bodies. The stories of feminist activists are often narrated in a heroic and celebratory tone. In these two texts, however, the underlying tone of defeat highlights the invisible, darker sides of resisting patriarchal structures, and the unhealed scars that these struggles leave on women's bodies. What is certain, though, is that these women's lives were ones of incessant, interlinked battles, externally as well as internally. 


\section{References}

Abboud, H. (2006) "Women in Prison: Zaynab al-Ghazali and her Days of my Life." Bahithat: Out of the Shadows: Investigating the Lives of Arab Women vol. IX. Beirut: Lebanese Association of Women Researchers. 268-89.

Al-Nowaihi, M. M. (2001). "Resisting Silence in Arab Women's Autobiographies." International Journal of Middle East Studies, 33(4): 477-502.

Bier, L. (2011). Revolutionary Womanhood: Feminisms, Modernity, and the State in Nasser's Egypt. Cairo, Egypt: The American University in Cairo Press. Print.

El-Zayyat, L. (1996). The Search: Personal Papers. London: Quartet Books. Print.

Enloe, C. H. (2000). Maneuvers: The International Politics of Militarizing Women's Lives. Berkeley, Calif: University of California Press. Print.

Feldman, A. (1991). Formations of Violence: The Narrative of the Body and Political Terror in Northern Ireland. Chicago: University of Chicago Press. Print.

Flax, J. (1987). "Postmodernism and Gender Relations in Feminist Theory." Signs, 12(4): 621-43.

Ghannam, F. (2013). Live and Die like a Man: Gender Dynamics in Urban Egypt. Palo Alto: Stanford University Press. Print.

Kandiyoti, D. (1996). Gendering the Middle East: Emerging Perspectives (1st ed.). London: I.B. Tauris. Print.

Lee, T. M. (2007). "Rethinking the Personal and the Political: Feminist Activism and Civic Engagement." Hypathia, 22(4): 163-79.

Nelson, C. (1996). Doria Shafik, Egyptian Feminist: a Woman Apart. Cairo, Egypt: American University in Cairo Press. Print.

Ramazanoglu, C. (1989). Feminism and the Contradictions of Oppression (1st ed.). GB: Routledge Ltd. Print.

Ruby, J. (2003). "Resistances to Patriarchy." Off Our Backs, 33(3/4): 38-40. Print. 